\title{
Christ: a Solution to Suffering in First Peter
}

P F Steenberg ${ }^{1}$

(University of Pretoria)

\section{ABSTRACT}

\section{Christ: a Solution to suffering in First Peter}

Christ is presented as a solution to suffering in first Peter. This is achieved by way of three main arguments. Firstly, a new identity is developed of which Christ forms the center. Secondly, the author provides hope, which includes eschatological hope that can be theirs only through Christ. Lastly, Christ is offered as the rational for endurance. His example is presented for the believers to follow. If the readers accepted the new identity in Christ, grasped onto the hope and followed the example of Christ, their suffering would become bearable in the present and be solved in the future.

The strange thing about Peter's ${ }^{2}$ writing on the topic of suffering is that he is not concerned with how to avoid suffering but rather with how to endure suffering (Geertz 1973:104). The idea that their suffering falls within the will of God can even be detected in $1: 6^{3}$. This does not necessarily imply that God is the cause of the suffering of the Christians, especially since it is God who gives them hope and salvation. Their suffering is thus directly related to God's will in providing them an

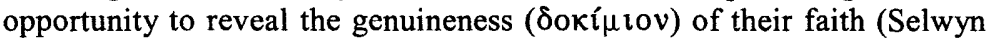
1981:129).

A three-fold solution forms part of the answer to the problem of suffering in the letter. Each solution finds its meaning in Christ (Elliott 1981:76,77):

a. Peter affirms a new identity in Christ.

b. The basis for their hope is Christ.

c. The rationale for endurance of suffering is Christ.

\footnotetext{
1 Post graduate student, Department of New Testament, University of Pretoria. Supervisor: Prof J G van der Watt.

${ }^{2}$ The authorship of first Peter is an introductory question and is therefore not under discussion here. The name "Peter" will be used in reference to the author.

${ }^{3}$ In 1:6 their various temptations / experiments $(\pi \varepsilon i \rho \alpha \sigma \mu o i \varsigma)$ are deemed necessary

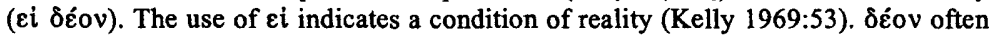
pertains to the will of God in the New Testament (Grundmann 1964:21-25).
} 
d. Each of these three solutions are explicit in the following texts:

\section{a. Peter affirms a new identity in Christ}

Their identity has been crushed since society has deemed them to be worthless. Peter gives them a new identity in Christ. Firstly, in 2:5 we read that Christians are "like living stones" to be built into a spiritual house, that they are to become a holy priesthood through Christ. Notice that they are not built upon living stones but that they are like living stones, in other words, like Christ. Their identity has now changed from outcast to "like Christ". That implies, that they share Christ's life in as much as they are now also elected and precious to God. Here Peter is concerned about their "corporate identity" . Corporately their identity is now being shaped into a "spiritual house" $(2: 5)$. This phrase must be seen in conjunction with the defining prepositional phrase (zic

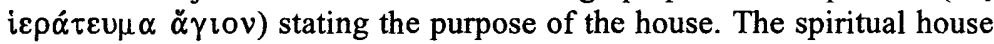
is best seen as a predicate nominative since the stones can only be seen as a house if they are seen corporately. In other words, they are being built up together. Their togetherness through the builder causes a new group and consequently a new identity.

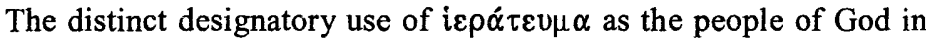
2:9 suggests a close relation between oíko $\varsigma \nu \in \cup \mu a \tau$ เ

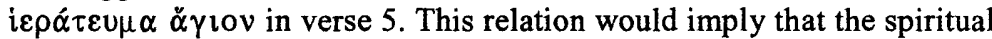
house belongs to God too and, consequently, so do the stones/Christians. This is confirmed if the adjective $\beta \alpha \sigma i \lambda \varepsilon i o v$ in 2:9 is read as a noun, in which case it bears the meaning of God's priesthood (Elliott 1966:149153). Although it is suggested that this verse is talking about a house or household (Elliott 1966:157-159) it is also possible for this house to be some kind of temple (a house for priests or priestly activity/priesthood) as some postulate (Michaels 1988:100). The purpose of Peter is thus to identify the house and by definition Christians as belonging to Jesus. The stone imagery appears to be derived from Isaiah 28:16. It is not clear whether the original thought referred to a cornerstone or a keystone over a door. However, this does not seem to be important, since the idea in both cases appears to be that this is the stone that keeps the others together (Reicke 1964:90). In the spiritual house, then, Jesus is the One who keeps them all together. If Jesus is the One who keeps them all together it supports the idea that Christians belong to Jesus. The designation in 2:5 as living stones also serves the purpose to add value. The idea of value might also be seen in the identification in 2:9 as royal. The

\footnotetext{
4 The term "corporate identity" in relation to Christ can be found in Michaels (1988:99).
} 
temple in Jerusalem is build with dead stones, but the new community is build from living stones thus possibly suggesting that they are of greater value (Barnes 1975:396). Furthermore, a spiritual house is not made of perishable materials. In the physical temple there were certain priests, but here all are priests in as much as they bring spiritual sacrifices that are acceptable to God. Spiritual sacrifices also play a part in Peter's affirmation of their new identity in Christ. The attribute that constitutes the sacrifices as acceptable to God is their relation to Christ. This thought is pronounced as follows:

"A distinct corporate identity in Jesus Christ is essential to the offering of authentic Christian worship" (Michaels 1988:101).

In fact, the work of a priest includes the offering of sacrifices. Logic demands that a spiritual house coupled with a holy priesthood leads to acceptable spiritual sacrifices, hence the following transpires:

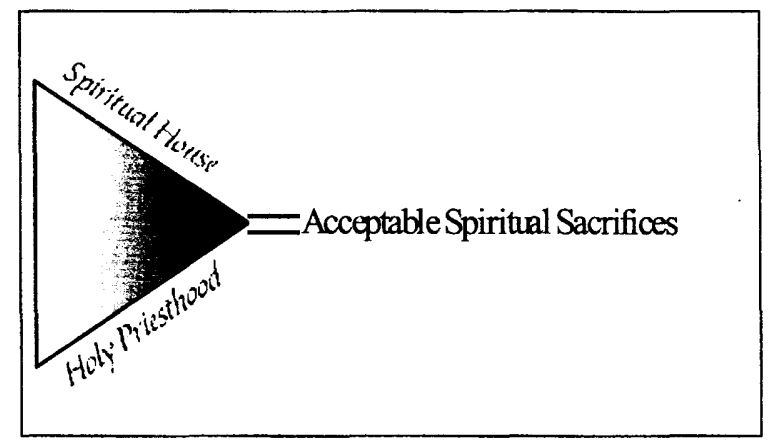

Figure 1

In figure 1 three components are found. The apex is formed by "acceptable sacrifices". It would appear that acceptable sacrifices could only be made in New Testament times through the other two components, viz. a spiritual house (temple) and a priesthood. These two components are not as acceptable on their own as when they are working in conjunction, hence their lighter print in the illustration. Peter now convinces them that they are both the spiritual house and the priesthood. Therefore, the deduction could be made that his readers form the ingredients for acceptable sacri- 


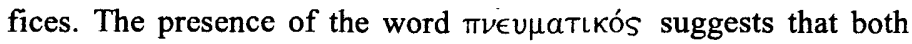
the priestly functions, and the house are used metaphorically. The fact that Peter calls the priesthood "holy" when holiness is already implied with the word priesthood may suggest that both holy and sacrifices refer to their conduct ${ }^{5}$ since they are used metaphorically. What makes the conduct acceptable to God is that it is offered through Jesus Christ. The word order confirms this because $\delta i \grave{\alpha}$

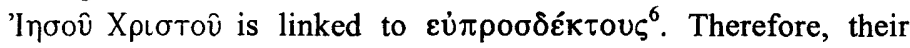
twofold new identity as belonging to God, and their good conduct is affirmed in Christ.

Secondly, the latter part of 2:6 promises that "he who believes in him will not be put to shame" (Revised Standard Version) ${ }^{7}$. Although this promise is negatively ${ }^{8}$ phrased it promises honour, which is the opposite of shame. The promise of honour is conditional to the condition of having faith in Jesus. Once again, their new identity as honourable in contrast to society's claim of shamefulness regarding Christians is affirmed in Christ ${ }^{9}$. The concept of honour is further enhanced with the positive words: $\dot{\varepsilon} \kappa \lambda \varepsilon \kappa \tau$ òv

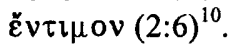

\footnotetext{
${ }^{5}$ There are similar examples of acceptable spiritual sacrifices referring to conduct. In Romans 12:1 this phrase refers to worship as doing God's will. In Hebrew 13:15,16 the phrase points to good deeds and praise to God.

${ }^{6}$ For a discussion of this particular word order and the implications thereof see Goppelt (1978:147).

${ }^{7}$ Note that Peter quotes Isaiah 28:16 here, which says: "Behold, I am laying in Zion a foundation, a stone, a tested stone, a precious cornerstone, of a sure foundation: 'He who believes will not be in haste"'. This very quotation is also used by Paul in Romans 9:33 which says: "Behold, I am laying in Zion a stone that will make men stumble, a rock that will make them fall; and he who believes in him will not be put to shame". It is rather interesting to note that the "original" text in Isaiah also happens to be a quotation. There is the possibility that Peter uses some quotations to add significance to what he says. In other words, he is saying that this is not just Peter saying so, it really is.

${ }^{8}$ Although this phrase is negatively formulated the negative is accentuated to make it absolutely negative. See the double negative Peter uses to assure his readers that they will not be put to shame: oú $\mu$ í.

${ }^{9}$ Although Peter does not use Christ in the affirmation of yet another identity he bestows on Christians, he does create a rather apt identity in 3:6 where their traditional roots come to the fore. However, that is not part of the discussion at this stage. ${ }^{10}$ The concept of honour would probably have been picked up by the readers due to the similarity and equation of Jesus and the readers with this terminology in such positive terms in 2:4-8. Also see $1: 2 ; 2: 9$.
} 


\section{b. The basis of their hope is Christ}

In the past the Jews have usually defined God in terms of the past traditions and their forefathers ${ }^{11}$. Here (1:3) Peter defines God in terms of Christ. Christ forms the basis of the whole text. By His great mercy Christians have been born again ( $\dot{\alpha} v \alpha \gamma \varepsilon v v \hat{\alpha} v)$. This term is a para ${ }^{12}-$ hapax legomenon in the sense that it only appears in first Peter $(1: 3$; $1: 23)$. A rather unique feature of this occurrence is the active form in which it appears. In fact, the aorist active participle could almost be seen as a title. Therefore, Christ is established as the basis of the rebirth and hope. The rebirth is oriented toward the future. It might even be eschatological since the believers are born again unto a living hope. That hope could also refer to the hope of the resurrection. This postulation is further supported with three prepositional phrases that point to the future,

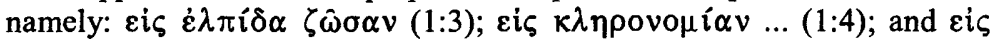
$\sigma \omega \tau \eta \rho i \alpha \nu$... (1:5). In this way Christ is the basis of hope.

A second allusion to Christ as the basis for hope is found in 1:13. The verse embarks with a familiar ${ }^{13}$ metaphor - the girding of loins. In previous occurrences (mentioned in the footnote) this metaphor refers to a state, but here it refers to action as can be seen in the aorist participial use of $\dot{\alpha} v \alpha \zeta \omega \sigma \alpha \dot{\alpha} \mu \varepsilon v o r$. The choice of $\dot{\alpha} v \alpha$-instead of $\pi \varepsilon p i$ - as prefix may also be a clue that we are dealing with an action. The genitive form $\tau \eta \hat{\zeta} \delta \delta_{1} \alpha$ voí $\alpha \zeta \dot{\mathrm{v}} \mu \hat{\omega} v$ gives notice that Peter is speaking metaphorically.

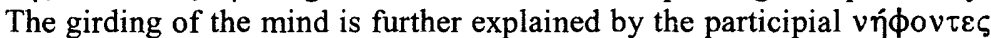
$\tau \varepsilon \lambda \varepsilon i \omega \varsigma .{ }^{14}$ Both the girding of the mind and the call for attentiveness is preparatory for the hope (which is in the imperative) ${ }^{15}$. Once again, the hope is to come to fruition through Jesus Christ. Although the hope is contemporary, the grace is eschatological and Christocentric, which makes Christ the basis of their hope.

A third insinuation that Christ is the basis of their hope can be found in 1:21. The text starts with the basis of that which is to follow,

\footnotetext{
${ }^{11}$ This was done by identifying God as the God of Abraham, Isaac and Jacob. Examples can be found in the synoptic gospels: Matt. 22:32; Mark 12:26 and Luke 20:37. Acts also boasts such occurrences in 3:13 and 7:32.

${ }^{12}$ The word "para" is used here, since this is not a true hapax because this word appears twice in the New Testament. However, both occurrences are in Peter. Since he is the only author in the New Testament to make use of this word it is deemed a "para" rather than purely a hapax.

${ }^{13}$ Familiarity with this metaphor can be seen in Ex. 12:11; Eph. 6:14; Prov. 31:17. Jesus even used this metaphor in Luke 12:35.

14 This is not a call to sobriety but rather to attentiveness and alertness (Michaels 1988:54-55).

${ }^{15}$ Peter scatters such aorist imperatives throughout the book. Examples of these in chapter one are: $\gamma \varepsilon v \eta \dot{\theta} \theta \eta \tau \varepsilon$ (1:15); $\dot{\alpha} v \alpha \sigma \tau \rho \alpha \dot{\phi} \eta \tau \varepsilon$ (1:17); $\dot{\alpha} \gamma \alpha \pi \eta \dot{\eta} \alpha \tau \varepsilon$ (1:22) (Michaels 1988:55). These serve the purpose of directing his readers.
} 


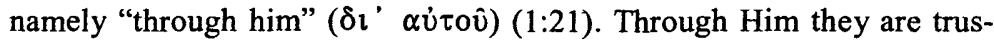
ting (having faith) in God who is the object of their trust. This phrase reminds them that they are believers in God through Jesus Christ, instead of through ancestral heritage $(1: 18)$. The text continues with the thought that glory follows the resurrection of Jesus, hence Christ is the solution to suffering. Christ was raised and given glory so that their faith and hope might be in God. This is so because the $\check{\omega} \sigma \tau \varepsilon$ - clause expresses intended result or purpose. Thus the intended result or purpose is achieved through Christ. Therefore, Christ is the basis of their hope.

1 Peter 5:7 states that Christ cares for us. Christ can also be the solution to suffering and provides hope. In 5:10 the readers are also promised a solution to suffering. Here Jesus plays a major role as the basis of the hope in that promise. In 3:21 the appeal to God is also accomplished through Jesus, who forms the basis of their hope. There are therefore many examples where Peter uses Christ as the basis for their hope against suffering.

\section{c. The rationale for endurance of suffering is Christ}

The example of Christ's life motivates the normality of suffering. In 2:21 Christians are being called to follow Christ's example of suffering.

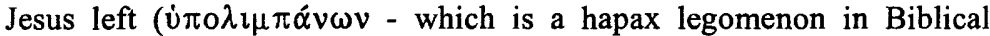
Greek) us His example. "In order that we might follow in His footsteps" is also a metaphor. Christ thus becomes the rationale for endurance and suffering.

Chapter 4:1 also refers to Christ's suffering as an example. It refers to an example because the author admonishes his readers to "arm" themselves with the same thought. Here we are dealing with a military metaphor o $\pi \lambda i \sigma \alpha \sigma \theta \varepsilon$. This fact is evident because of the use of $\tilde{\varepsilon} v v o l \alpha$. When this phrase is viewed in isolation it could well imply that martyrdom is desired ${ }^{16}$. However, in the context of the whole book ${ }^{17}$, they are to endure with the attitude that Jesus had. Therefore, the way in which Jesus suffered becomes a rationale for endurance and suffering. The way in which Peter refers to Christ's suffering as culminating in glorification connects the two concepts for the readers, thus suffering and glorification are bound closely together.

Further, in the same chapter we find that Christians are to rejoice in sharing Christ's suffering (4:13).

\footnotetext{
${ }^{16}$ Whether or not this refers to martyrdom see Michaels (1988:225).

${ }^{17}$ We know that this is the message on suffering in Peter because: a. It does not appear as if Peter concludes or even suggests that suffering in itself is a good thing; b. Peter does not talk well of suffering per se, but of suffering for doing good; c. Peter is attempting to give them hope, and Christ is the object of that hope and not suffering.
} 


\section{First Peter 4:13}

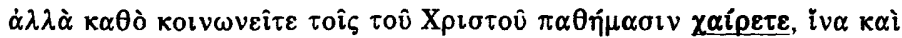

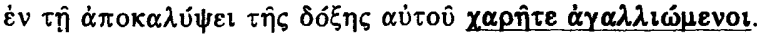

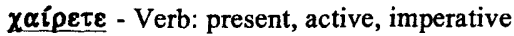
$\chi \alpha \rho \eta \hat{\tau}$ - Verb: aorist, passive, subjunctive $\underline{\alpha} \gamma \alpha \lambda_{1} \hat{\omega} \mu \varepsilon v o l$ - Verb: present, nominative Also see 1:6

Figure 2

In Figure 2 the concept of rejoicing appears three times. It is evident that future suffering is not being talked about. Nor does it talk about the possibility of suffering. It states that they are suffering. The idea that they are to suffer as Christ did is nothing new in Peter ${ }^{18}$. Peter is not referring to a sacramental, mystical union with Him, but to similar circumstances. This is shown by the comparative $\kappa \alpha \theta$ ò that suggests similarity to Christ's circumstances and behaviour in various conditions. The rejoicing $(\chi \alpha i \rho \varepsilon \tau \varepsilon)$ is used in the present and imperative here. This signifies joy in suffering and not suffering with future joy ${ }^{19}$. Once again the idea is not to rejoice because of suffering but rather to rejoice for suffering unjustly $(2: 19 ; 2: 20 ; 3: 14,16)$. As Christ was faithful in the midst of suffering so the Christian needs to be faithful in similar circumstances. This thought is worded as follows:

"Not all who suffer, but rather those who show themselves faithful in suffering, are invited to rejoice, now because they are following Christ's example and in the future because they will share his glory" (Michaels 1988:262).

Here too, then, we find that Christ and His example of dealing with suffering serves as rationale for endurance and suffering. Similarly, in 5:10 we find that their suffering also follows their calling through Christ. Therefore, Christ's calling or God's calling through Christ precedes suffering. If we look chronologically (through the book of first Peter) at the response to suffering we find the following:

\footnotetext{
${ }^{18}$ The concept permeates the whole book, see $2: 19-21 ; 3: 17-18 ; 4: 1$.

${ }^{19}$ Nauck (1955:73-76) finds the same thought in 1:6-8.
} 


\begin{tabular}{|c|c|}
\hline$\underline{\mathbf{A}} \underline{\mathbf{B}}$ & $\begin{array}{l}1: 6-\text { you are to rejoice: } \dot{\alpha} \gamma \alpha \lambda \lambda \iota \hat{\alpha} \sigma \theta \varepsilon \text { verb: present, indicative } \\
2: 19,20 \text { - you are commended/approved/graced: } \chi \dot{\alpha} \rho \iota \varsigma \text { noun: nominative }\end{array}$ \\
\hline$\underline{\mathbf{A}}$ & $\begin{array}{l}\text { C } \quad 3: 14-\text { you are blessed: } \mu \alpha \text { Kó } \rho\llcorner o l \text { adjective: nominative } \\
4: 13-\text { you are to rejoice: } \chi \alpha \hat{\imath} \rho \varepsilon \tau \varepsilon \text { verb: present, imperative }\end{array}$ \\
\hline$\underline{\mathbf{B}}$ & 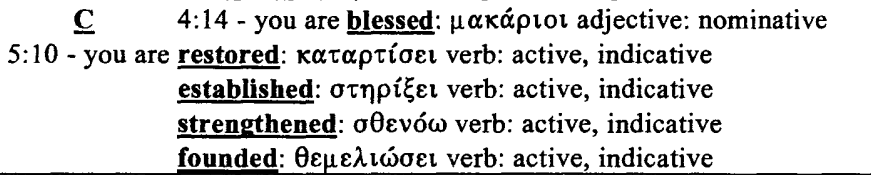 \\
\hline
\end{tabular}

Figure 3

Figure 3 shows us, firstly, that the Christian's response to suffering should be to rejoice. In both cases the rejoicing is present rather than future. Secondly, God responds dualistically to the suffering of the believers. He grants His approval and grace, which have to do with His honour and shame verdict. He also follows that up with action, viz. He restores, establishes, strengthens and creates their foundation $(5: 10)$. Lastly, they are blessed in response to suffering. The second and third responses provide a reason for the first response. By looking to Christ the present negative reality becomes bearable and even joyful.

The author of first Peter dealt with the suffering problem in three ways. He changed their identity into Christocentricity. He provided them with hope. That hope is only attainable in Christ. The example of Christ was put forth not only as the rational for suffering, but also as the agent to change suffering into joy. In each of these three steps Christ is the core. Hence Christ is a solution to suffering in first Peter.

\section{Consulted literature}

Balz, H 1991. $\mu \tau \alpha$ los. in Exegetical Dictionary of the New Testament. Editors: Balz, H and Schneider, G. Grand Rapids. Volume 2, 396.

Barnes, A 1975. Notes on the New Testament: Explanatory and Practical (Ed: Frew, R), Baker Book House, Grand Rapids.

Elliott, J H, 1966. The Elect and the Holy: An Exegetical Examination of 1 (sic) Peter 2:4-10 and the Phrase ' $\beta \alpha \sigma$ í Supplements, 12. Leiden.

-, 1990. A Home for the Homeless: A sociological Exegesis of 1 Peter, Its Situation and Strategy. Philadelphia.

Geertz, C 1973. The Interpretation of Cultures: Selected Essays. New Testament: Basic.

Goppelt, L 1978. Der erste Petrusbrief. Eighth Edition. (Ed: Hahn, F) Göttingen.

Grundmann, W 1964. $\delta \hat{\eta} \mu \circ \varsigma, \dot{\varepsilon} \kappa \delta \eta \mu \varepsilon ́ \omega, \dot{\varepsilon} v \delta \eta \mu \varepsilon \omega$. in Theological Dictionary of the New Testament. (Ed: Kittel, G) (Translated: Bromiley, G W) Grand Rapids, Volume 2, 63-65.

Kelly, J N D 1969. The Epistles of Peter and of Jude. in Black's New Testament Commentary. London.

Michaels, J R 1988. 1 Peter. in Word Bible Commentary 49. Waco. 
Nauck, W 1955. Freude im Leiden. Zum Problem einer urchristlichen Verfolgungstradition. Zeitschrift für die neutestamentliche Wissenschaft, 46:68-80.

Reicke, B 1964. The Epistles of James, Peter, and Jude. In The Anchor Bible. New York. Volume 7.

Selwyn, E G 1981. The First Epistle of St. Peter. Second Edition. Grand Rapids. 